\title{
Development of Smart Human Resource Planning System within Rajabhat University
}

\author{
Kittisak Singsungnoen ${ }^{1}$, Panita Wannapiroon ${ }^{1}$ \& Prachyanun Nilsook ${ }^{1}$ \\ ${ }^{1}$ Division of Information and Communication Technology for Education, Faculty of Technical Education, King \\ Mongkut's University of Technology North Bangkok, Thailand
}

Correspondence: Kittisak Singsungnoen, Division of Information and Communication Technology for Education, Faculty of Technical Education, King Mongkut's University of Technology North Bangkok, Thailand. Tel: 66-613-826-151. E-mail: kittisak.sing@vru.ac.th

Received: February 14, 2021

doi:10.5539/hes.v11n2p139
Accepted: March 27, $2021 \quad$ Online Published: April 1, 2021

URL: https://doi.org/10.5539/hes.v11n2p139

\begin{abstract}
The purposes of this study were to 1) develop of Smart Human Resource Planning System within Rajabhat Universities and 2) study the results of official performance evaluations of academic staff with Smart Human Resource Planning System within Rajabhat Universities. The samples included 8 system development experts via purposive sampling and 94 academic staff by multi-stage sampling. The research tools composed of 1) performance assessment form using 5-point Likert scale for Smart Human Resource Planning within Rajabhat Universities and 2) performance evaluation form for academic staff with Smart Human Resource Planning System within Rajabhat University. The research observations were concluded into 2 ways. First, the Smart Human Resource Planning System within Rajabhat Universities development has overall performance at the high level. For instance, the efficiency of all Modula test was displayed at the high level. In addition, both System test, Usability test and Security test were shown at high level as well. Second, the response of performance evaluation form through academic staff using Smart Human Resource Planning System was all exhibited at high level. However, "The people involved with the system" assessment list with in performance evaluation form was indicated at highest level.
\end{abstract}

Keywords: human resource planning, smart, rajabhat university

\section{Introduction}

\subsection{Introduce the Problem}

According to the announcement on information technology and communication Policy Framework of Thailand during 2001-2010 and information technology and communication Policy Framework of Thailand during 2011-2020 or SMART Thailand 2020 (Ministry of Information and Communication Technology, 2011) which have been the Master Plan on information Technology and communication of Thailand. In this regard, it has determined its vision that information Technology and communication has been a major stimulus in bringing Thai people to have knowledge and wisdom, sustainable Thai economy, equality of Thai Society. Also, it has designated the goal and strategy in developing various aspects (Wannapiroon \& Nilsook, 2012; Nilsook \& Jitsupa, 2013).

The Office of Civil Service Commission has studied about problems arising concerning the assessment of public service performance. It has pointed that there have been several problems such as unclarity of assessment, fairness in assessment, morality and skills of evaluators while applying their emotion during assessment. It has also been evaluated one-side from supervising level or even some cases; it has been undertaken compromisingly in order that it could be an irrelevant assessment according to its intent, understanding in assessment model and assessment method among evaluators and clients. This has not yet come up with any developments. Therefore, the Office of the Civil Service Commission's goal in developing and applying a new regime in public service system namely; development a system and tools which reflect the reality and benefits for users and create some understanding among evaluators and their clients including the Performance Management System (Office of the Civil Service Commission, 2008).

The component of assessment on civil service performance for academic university staff has two aspects; namely 
result-based one comprising of various indicators such as teaching, research and creative activity, academic service, fostering art and culture, developing students work, other work according to university missions and behavioral factors of civil service performance (competency) (Singsungnoen, Wannapiroon \& Nilsook, 2018).

This research purpose is to develop the smart human resource planning in Rajabhat university. In this regard, data concerning components and assessment criteria on civil service performance which was undertaken during data synthesis process in order to develop the smart human resource planning in Rajabhat university.

\section{Research Objectives}

The purposes of this study were

To development of Smart Human Resource Planning System within Rajabhat University

To study the results of official performance evaluation of Academic staff with Smart Human Resource Planning System within Rajabhat University.

\section{Conceptual Framework}

The study is research and development for Smart Human Resource Planning System within Rajabhat University.

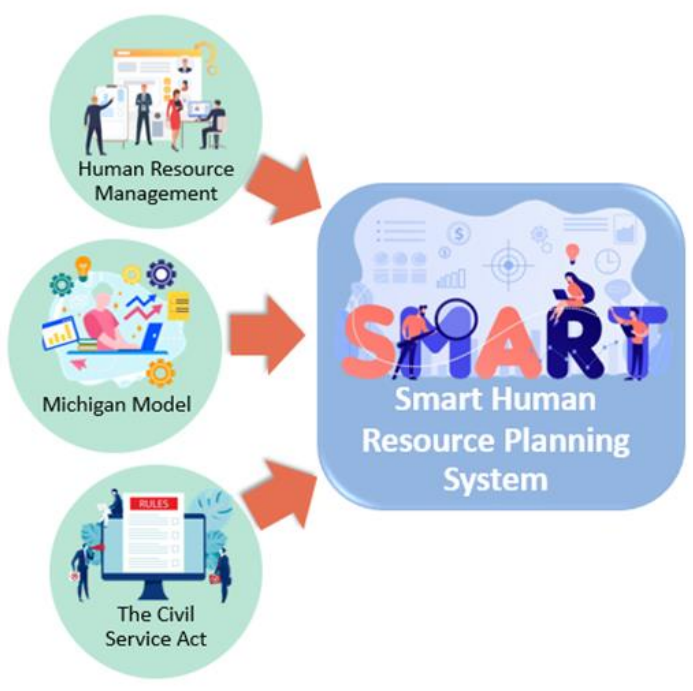

Figure 1. Conceptual Framework of Research

\section{Related Literature}

\subsection{Enterprise Resource Planning: ERP}

Enterprise Resource Planning is an information system or software to be used for manage and plan for utilize various resource in organization by applying information system within an organization such as human resource management system, finance and accountancy management system, customer relations system and other systems to be linked and transmitted via such mentioned systems in order to make any organizations effective, beneficial, competitive, reduction of process making while turning an organization into an organization of value chain (Kamolchaipisit, 2013; Microsoft, 2015; Mesbahi, Kazar, Zoubeidi \& Benharzallah, 2015; Jahanian, 2009).

\subsection{Human Resource Management}

Human resource planning is a process of which any organizations manipulate to handle human resource concerning a process of forecast a requirement for human resource for an organization consisting of the following procedures :1) To study on current organization data, 2) To study on human resource in the present, 3) To study on need of human resource in the future, 4) To make a comparison between a requirement on human resource towards organization and a requirement of human resource in the future, 5) Work analysis, 6) Recruitment and selection, 7) Human resource development, 8) Performance assessment and 9) Compensation payment (Chand, n.d; Prashanthi, 2013; HRwale, n.d.; Anthony, 2002).

\subsection{Michigan Model of HRM}

Michigan Model of HRM or another term called as a model of managerialism which concentrates on a priority of 
a benefit returns that any organizations would gain at first and allows workforce or human resource management to be a tool to be achieved towards a goal of an organization. Therefore, a model of HRM is regarded as a major mechanism to drive any organizations to be better productive comprising of 4 procedures, namely selection and recruitment, performance assessment, rewarding and compensation, training and development (Tapawan, 2011).

\subsection{Performance Evaluation by a Performance Management System}

The assessment pursuant to public service performance assessment is a kind of a result-based assessment as mutually agreed. In this regard, there will be a determination on performance indicators and target value including a behavior on public service performance referring to competency. The score point of public service assessment derived from two components, namely performance result and a behavior on public service performance or competency of which the weighting output was set as ratio: 70:30 or 80:20 appropriately in each organization. There will be twice assessment in each year in a fiscal budget according to the announcement of the Permanent Secretary Office of Ministry of Education on criteria and assessment procedures on public service performance of civil servant under the Permanent Secretary Office of Ministry of Education B.E. 2558. It has designated the assessment on public service performance be done twice a year according to the yearly fiscal budget and three factors of assessment are 1) result -based performance with score ratio at $70 \%$ by evaluating from work quantity, work quality and rapidness or timely due or saving up or worth of resources deployment or others when the supervising level have already considered appropriately. 2)The behavior in public service performance with the scoring point ratio at $20 \%$ by evaluating from core competency and managerial competency and functional competency as follow: 2.1) Core Competency consisting of achievement motivation, service mind, expertise, integrity and ethics and teamworking. 2.2) Managerial Competency consisting of leadership, vision, strategic public service for change, self-control, coaching and empowerment and 2.3) Functional Competency consisting of analysis, holistic perspective, caring and developing others, directing according to holding people accountable, data searching, understanding in cultural differences and others, recognition in organization and bureaucracy, proactive performance, checking up the correctness of procedures, self-confidence, flexibility, aesthetic quality, engagement in public service and relation making. 3) Good attributes according to Civil service code of ethics and the regulation on civil service ethics with scoring ratio at $10 \%$ by evaluating from designated organizational assessment (Office of the Civil Service Commission, 2009; Valaya Alongkorn).

\section{Research Methodology}

\subsection{Phase I: Systematic Development}

In this research, the researcher has applied the System Development Life Cycle SDLC as a model for developing system as follows

\subsubsection{Stage I Study and Analysis}

To study and analyze document, articles, books, textbooks related with components of human resource planning system both inbound and outbound and make a systhesis and summary the components of human resource planning system. After that, bringing up derived components to be interviewed and appraised the appropriateness of the human resource planning system with some experts in order to sum up the components of human resource planning system. To synthesize the components of criteria on public service performance of university staff in Rajabhat Universities according to the announcement and evaluation criteria on public service performance of Civil Service Commission for Higher Educational Institute and Rajabhat Universities in Thailand and bring in the assessment criteria on public service performance to evaluate the appropriateness of 80 academic university staff.

\subsubsection{Stage II Design}

Apply the components of human resource planning system and criteria on public service assessment for university staff in Rajabhat Universities to design an architecture of the Smart Human Resource Planning System in Rajabhat Universities and to appraise the appropriateness of components of architecture of the Smart Human Resource Planning System in Rajabhat Universities together with 5 experts in field of information technology design.

\subsubsection{Stage III Development}

Apply the architecture of the smart human resource planning system in Rajabhat Universities to develop the smart human resource planning system in Rajabhat Universities and to evaluate effectiveness of the smart human resource planning system in Rajabhat Universities together with 8 experts in field of information technology design. 


\subsection{Phase II: Assessment}

\subsubsection{Stage I}

To arrange a training by using the smart human resource planning system in Rajabhat Universities for all personnel of the Faculty of Science and Technology in Valaya Alongkorn Rajabhat University in the Royal Patronage and collect assessment data of the performance result of Academic university staff by applying the smart human resource planning system in Rajabhat Universities.

\subsubsection{Stage II}

To evaluate the result of performance of the academic university staff with the application of smart human resource planning system. The sample group was 94 academic university staff.

\subsubsection{Stage III}

To analyze and summarize the assessment result on performance of academic university staff with the application of the smart human resource planning system within Rajabhat university.

\section{Research Results}

6.1 The Result of Develop the Smart Human Resource Planning System within Rajabhat Universities

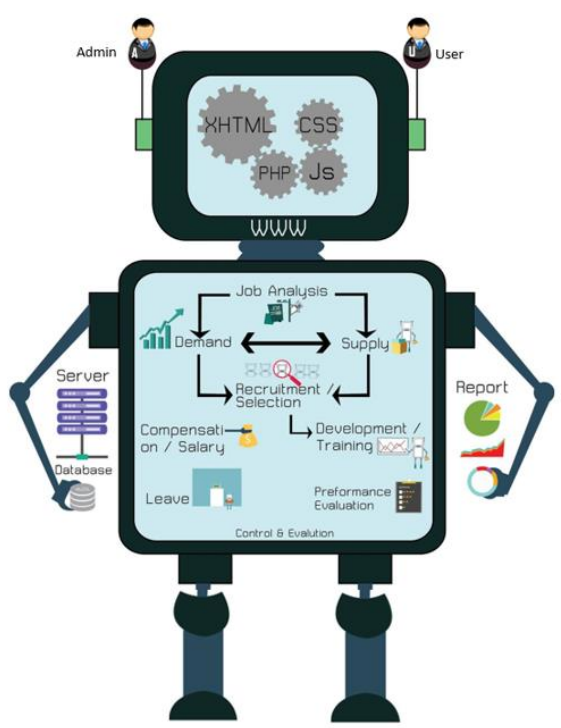

Figure 2. Conceptual Framework of Smart Human Resource Planning System in Rajabhat University

From figure 2 represents to system component consisting of 1) The User consists of an administrator, HR staff, Dean and University staff. 2) Database 3) Job Analysis 4) Demand Forecast 5) Supply Forecast 6) Comparison 7) Recruitment / Selection 8) Salary / Compensation 9) Training / Development 10) Leave 11) Performance Evaluation 12) Control and Evaluation and 13) Report 


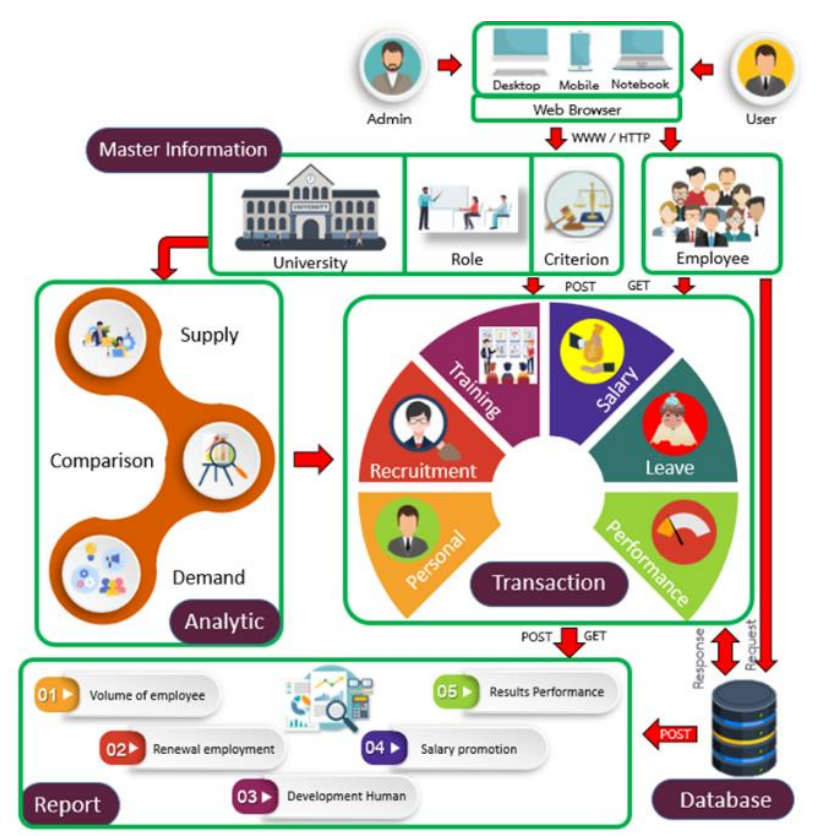

Figure 3. Architecture of Smart Human Resource Planning System in Rajabhat University

Table 1. The evaluate effectiveness of the smart human resource planning system within Rajabhat Universities

\begin{tabular}{lccl}
\hline Assessment list & \multicolumn{2}{c}{ Evaluateion } & Effectiveness \\
\cline { 2 - 3 } & $\bar{X}$ & S.D. & \\
\hline 1. Module Test & & & \\
1.1 Employee Module & 4.19 & 0.76 & High \\
1.2 University Module & 4.23 & 0.78 & High \\
1.3 Role Module & 4.35 & 0.84 & High \\
1.4 Criterion Module & 4.23 & 0.78 & High \\
1.5 Academic works Module & 4.25 & 0.76 & High \\
1.6 Performance Module & 4.23 & 0.72 & High \\
2. System Test & 4.33 & 0.72 & High \\
3. Usability Test & 4.23 & 0.90 & High \\
4. Security Test & 4.33 & 0.70 & High \\
\hline
\end{tabular}

From table 1 the evaluate effectiveness of the smart human resource planning system within Rajabhat Universities together with 8 experts found that 1 ) The Module Test is every module is the overall efficiency at a high level. 2) The System Test is efficiency at a high level. 3) The Usability Test is efficiency at a high level and 4) The Security Test is efficiency at a high level.

6.2 The Result of Performance of the Academic University Staff with the Application of Smart Human Resource Planning System

Table 2. The result of performance of the academic university staff with the application of Smart Human Resource Planning System

\begin{tabular}{lccl}
\hline Assessment list & \multicolumn{2}{c}{ Evaluateion } & Satisfaction \\
\cline { 1 - 3 } & $\bar{X}$ & S.D. & \\
\hline 1.The people involved with the system & 4.55 & 0.74 & Highest \\
2.The data management of system & 4.39 & 0.78 & High \\
3.The data entry of system & 4.49 & 0.73 & High \\
4.The system process & 4.43 & 0.69 & High \\
5.The system reports & 4.30 & 0.67 & High \\
\hline
\end{tabular}


From table 2 result of performance of the academic university staff with the application of Smart Human Resource Planning System by sample group found that 1) The people involved with the system has satisfaction at a highest level 2) The data management of system has satisfaction at a high level 3) The data entry of system has satisfaction at a high level 4) The system process has satisfaction at a high level and 5) The system reports have satisfaction at a high level.

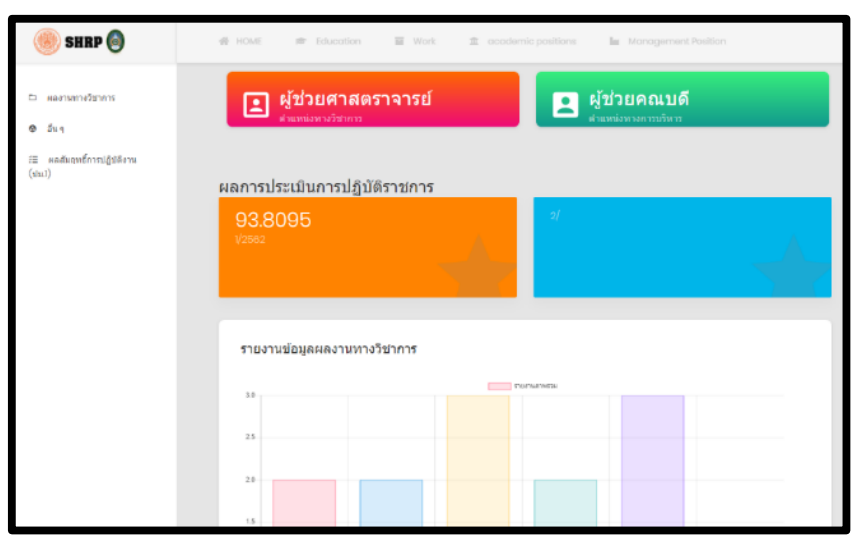

Figure 4. Academic Staff Information

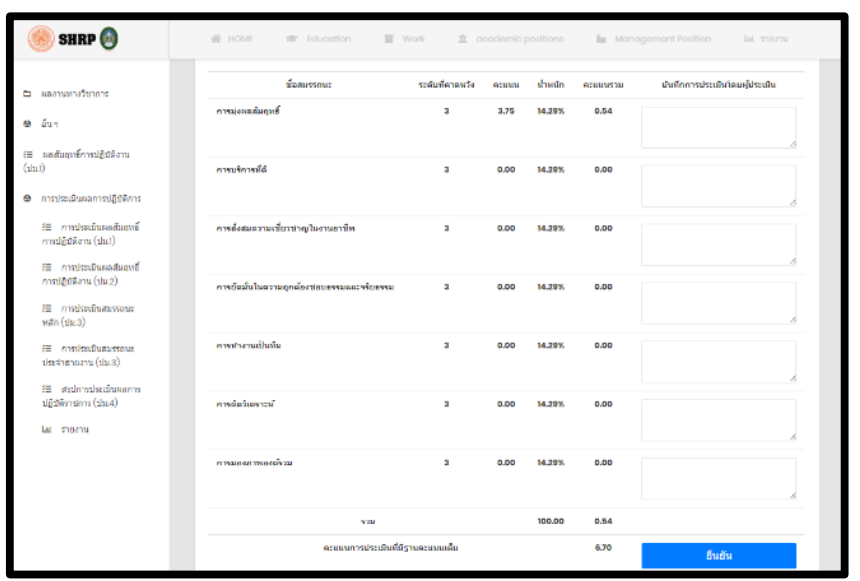

Figure 5. Performance Evaluation

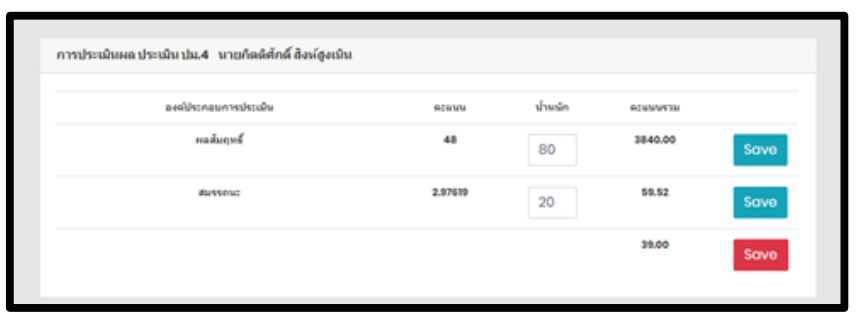

Figure 6. Performance Appraisal Summary

\section{Discussion}

The development of Smart Human Resource Planning System according conceptual framework of Smart Human Resource Planning System in Rajabhat University consists 13 components 1) User component 2) Database component 3) Job Analysis component 4) Demand Forecast component 5) Supply Forecast component 6) Comparison component 7) Recruitment / Selection component 8) Salary / Compensation component 9) Training / Development component 10) Leave component 11) Performance Evaluation component 12) Control and Evaluation component and 13) Report component. The system process consistent with the process of 
government performance evaluation process, civil service act b.e. 2008 and performance evaluation manual of the Civil Service Commission of the Office of the Civil Service Commission. The Smart Human Resource Planning System follows the concept of the Michigan model of human resource management. Th model is used by the Civil Service Commission as a model for human resource management in the Civil Service.

The result studies of performance evaluation of the academic university staff with the application of Smart Human Resource Planning System. The researcher has implemented Smart Human Resource Planning System trial to 94 academic university staff sample group by define evaluation criteria according to the performance evaluation manual of Valaya Alongkorn Rajabhat University under the Royal Patronage. The result from testing of the systems by the sample group found that the sample group has satisfaction at a high level.

\section{Acknowledgments}

The researchers would like to thank you Division of Information and Communication Technology for Education, Faculty of Technical Education, Innovation and Technology Management Research Center and Vocation Education Technology Research Center, King Mongkut's University of Technology North Bangkok which support this research, Faculty of Science and Technology, Valaya Alongkorn Rajabhat University under the Royal Patronage.

\section{References}

Anthony, W. P., Perrewe, P. L., \& Kacmar, M. K. (2002). Human Resource Management: A Strategic Approach. Orlando: Harcount College Publishers.

Chand, S. [n.d.]. HRP: Human Resource Planning: Meaning, Definition and Features. Retrieved from http://www.yourarticlelibrary.com/essay/hrp-human-resource-planning-meaning-definition-and-features/25935

HRwale. [n.d.]. HUMAN RESOURCES PLANNING. Retrieved from http://www.hrwale.com/general-hr/human-resources-planning/

Jahanian, R. (2009). Improving method of Tehran training and education, knowledge in training science, lesson planning. Islamic Azad University of Khorasgan (Esfehan), 24(6), 61-84.

Kamolchaipisit, K. (2013). Enterprise Resource Planning in Cloud Computing: Opportunities and Challenges. Journal of Vocational and Technology Education, 3(6), 75-82.

Maha Sarakham Rajabhat University, [n.d.]. Regulations of Rajabhat Maha Sarakham University on Criteria and method for evaluating the performance of civil servants in higher education institutions Rajabhat Mahasarakham University 2011. Retrieved from http://personal.rmu.ac.th/web/ rules.php

Mesbahi, N., Kazar, O., Zoubeidi, M., \& Benharzallah, S. (2015). An Agent-Based Modeling for an Enterprise Resource Planning (ERP). International Journal of Decision Support System Technology, 551, 225-234. https://doi.org/10.1007/978-3-319-05503-9_22

Microsoft. [n.d]. What is enterprise resource planning (ERP)?. Retrieved from http://www.microsoft.com/en-us/dynamics/ what-is-erp.aspx

Ministry of Information and Communication Technology. (2011). Thailand Information and Communication Technology Policy Framework 2011-2020 (ICT2020). Bangkok: Ministry of Information and Communication Technology.

Nakhon Pathom Rajabhat University. [n.d.]. Regulations of Nakhon Pathom Rajabhat University on Criteria and method for evaluating the performance of personnel in Nakhon Pathom Rajabhat University 2011. Retrieved from http://www2.npru.ac.th/webdev/laws/ index.php?type=4

Nilsook, P., \& Jitsupa, J. (2013). Information and Communication Technology Administration for Education. Bangkok: Book Center King Mongkut's University of Technology North Bangkok.

Office of the Civil Service Commission. (2008). Civil Service Act 2008. Nonthaburi: Office of the Civil Service Commission.

Office of the Civil Service Commission. (2008). The strategic plan for human resource management approach HR Scorecard. Bangkok: P.A Living.

Office of the Civil Service Commission. (2009). Performance evaluation manual: Overview of Performance Management System and Public Performance Evaluation System. Nonthaburi: Office of the Civil Service Commission.

Prashanthi, K. (2013). Human Resource Planning - An Analytical Study. International Journal of Business and 
Management Invention 2013, 2(1), 63-68.

Singsungnoen, K., Wannapiroon, P., \& Nilsook, P. (2018). Synthesis of Elements of Criteria for Performance Evaluation for University Academic Staff. TNI Journal of Business Administration and Languages, 6(2), 43-51.

Tapawan, P. (2011). Strategic human resource management. Bangkok: SE-Education. 2011.

Udon Thani Rajabhat University. [n.d.]. Announce of Udon Thani Rajabhat University on Criteria and method for evaluating the performance of civil servants in higher education institutions 2011. Retrieved from http://www.udru.ac.th/udrucouncil/ images/document/staff/01/Rules_2554.pdf

Valaya Alongkorn Rajabhat University under the Royal Patronage. [n.d.]. Announce of Valaya Alongkorn Rajabhat University under the Royal Patronage Pathum Thani on Criteria and Method for Evaluating the Performance of University Employees 2011.

Wannapiroon, P., \& Nilsook, P. (2012). The Development of Web-Based Training for Job Competencies of Academic and Administrative Staff of King Mongkut's University of Technology North Bangkok. International Journal of e-Education, e-Business, e-Management and e-Learning, 2(5), 348-352. https://doi.org/10.7763/IJEEEE.2012.V2.144

\section{Copyrights}

Copyright for this article is retained by the author(s), with first publication rights granted to the journal.

This is an open-access article distributed under the terms and conditions of the Creative Commons Attribution license (http://creativecommons.org/licenses/by/4.0/). 